\title{
Climate forcing of tree growth in dry Afromontane forest fragments of Northern Ethiopia: evidence from multi-species responses
}

\author{
Zenebe Girmay Siyum ${ }^{1,2^{*}}$, J. O. Ayoade ${ }^{3}$, M. A. Onilude ${ }^{4}$ and Motuma Tolera Feyissa ${ }^{2}$
}

\begin{abstract}
Background: Climate-induced challenge remains a growing concern in the dry tropics, threatening carbon sink potential of tropical dry forests. Hence, understanding their responses to the changing climate is of high priority to facilitate sustainable management of the remnant dry forests. In this study, we examined the long-term climategrowth relations of main tree species in the remnant dry Afromontane forests in northern Ethiopia. The aim of this study was to assess the dendrochronological potential of selected dry Afromontane tree species and to study the influence of climatic variables (temperature and rainfall) on radial growth. It was hypothesized that there are potential tree species with discernible annual growth rings owing to the uni-modality of rainfall in the region. Ring width measurements were based on increment core samples and stem discs collected from a total of 106 trees belonging to three tree species (Juniperus procera, Olea europaea subsp. cuspidate and Podocarpus falcatus). The collected samples were prepared, crossdated, and analyzed using standard dendrochronological methods. The formation of annual growth rings of the study species was verified based on successful crossdatability and by correlating tree-ring widths with rainfall.

Results: The results showed that all the sampled tree species form distinct growth boundaries though differences in the distinctiveness were observed among the species. Positive and significant correlations were found between the tree-ring widths and rainfall, implying that rainfall plays a vital role in determining tree growth in the region. The study confirmed the formation of annual growth rings through successful crossdating, thus highlighted the potential applicability of dendroclimatic studies in the region.

Conclusions: Overall, the results proved the strong linkage between tree-ring chronologies and climate variability in the study region, which further strengthens the potential of dendrochronological studies developing in Ethiopia, and also has great implications for further paleo-climatic reconstructions and in the restoration of degraded lands. Further knowledge on the growth characteristics of tree species from the region is required to improve the network of tree-ring data and quality of the chronology so as to successfully reconstruct historic environmental changes.
\end{abstract}

Keywords: Climate-growth relationship, Climate change, Dry Afromontane forest, Restoration, Tree-ring width

\footnotetext{
* Correspondence: zenebegirmay@gmail.com

'Pan African University, Life and Earth Sciences (including Health and

Agriculture) Institute, University of Ibadan, Ibadan, Nigeria

${ }^{2}$ Wondo Genet College of Forestry and Natural Resource, Hawassa University,

P.O. Box 128, Shashemene, Ethiopia

Full list of author information is available at the end of the article
} 


\section{Background}

Accounting for about 25\% of the global terrestrial carbon (Bonan 2008), tropical forests play a crucial role in regulating regional and global climate dynamics (Lewis et al. 2009; Zhou et al. 2013). The dry forests and woodlands in particular harbor diverse and multifunctional landscapes, thus play vital roles in supporting vulnerable households at times of hardships (including those increasingly affected by climate change and variability) (Blackie et al. 2014). However, the climate-induced challenge remains a growing concern in the dry tropics and is threatening the counterbalancing potentials of these ecosystems (IPCC 2007, 2013). Studies documented the dynamics of these ecosystems along with the mechanisms by which the diverse species and their ecology coexist in the face of global changes. But, most studies undertaken on tropical forest dynamics paid much attention to inventories from permanent plots and plant physiological experiments (Lewis et al. 2009). Even though such monitoring plots provided much of the evidence for understanding tropical forest dynamics, they have shortfalls in that they accounted only for short time horizons and limited areas (Lewis et al. 2009; Zhou et al. 2013). This hindered understanding of the long-term responses and feedback of tropical forests to global changes (including climate change).

Tree species in the dry tropics are predicted to be particularly sensitive to the unprecedented climatic changes. Due to the expected heightened warming and drying, tropical trees will likely experience slow growth and high mortality rates (Nath et al. 2006; IPCC 2007). So, in the absence of a thorough understanding of the climate-growth relations of these tree species, it is difficult to make inferences on the responses of dry forests to the changing climate. This entails that there is a dire need to intensify such studies in the dry tropics, and this, in turn, requires long-term datasets on growth and climate relations (Clark 2007). In view of this, shifts in research approaches were observed over the past few decades, targeted at addressing the gaps of forest monitoring studies which used permanent sample plots. Of the various approaches, tree-ring study has been identified as a powerful tool to study climate-growth relationships and thereby rectifying the scarcity of long-term growth data for tropical forest trees (Rozendaal and Zuidema 2011; Zuidema et al. 2012, 2013). Tree-ring research is generally envisaged to provide the much-needed long-term data on tree growth and tree recruitment. Tree-ring research in the tropics is increasingly being employed in a range of applications, for instance, to understand forest dynamics, determine forest age structure, construct lifetime growth trajectories, predict timber yield, estimate minimum age for use and understand climate-growth relationships (e.g. Fichtler et al. 2004; Brienen and Zuidema 2005; Trouet et al. 2006; Gebrekiristos et al. 2008; Rozendaal and Zuidema 2011; Tolera et al. 2013). In general, the available evidence proved the potential of tree-ring studies for understanding the dynamics of tropical forests and their sensitivity to the changing climate through the provision of reliable results (Brienen et al. 2016).

Despite the continued success stories on the wide applicability of tree-ring research in the tropical regions, the formation of annual growth rings in tropical forest trees was once doubtful (Lieberman et al. 1985) and still remains controversial (Worbes 2002). There is a notable lack of intensive tree-ring study in the tropics and thus relatively fewer tree species have been documented compared to the temperate and boreal regions where a dense network of tree-ring data exists (Wils et al. 2011a). Hence, more widespread application of rigorous tree-ring studies will yield important insights into the mechanisms that govern tree growth and forest dynamics in these regions. Such knowledge is highly valuable to understand past growth patterns and dynamics of tree resources in relation to ecological factors (Brienen and Zuidema 2005), and in assessing how tropical forests will respond to the predicted climate changes.

In regions with distinct climate seasonality, tree species are forced to enter into periodic dormancy, thus tend to form annual growth rings (Fritts 1976, pp. 1-25). But, their radial growth (i.e., the activity of vascular cambium) is influenced not only by climate, but also by a range of environmental and genetic factors (Cook 1987), and indeed their interaction effects. This implies that the formation of different anatomical wood features is both species-and site-specific. In the tropics, the formation of annual tree-rings was reported in association to various factors; for instance, seasonality in rainfall (Worbes 1999), day length (Borchert and Rivera 2001), temperature (Fichtler et al. 2004) and even flooding (Schongart et al. 2002). The different dendrochronological studies conducted for various tropical tree species (e.g. Stahle et al. 1999; Worbes 1999; Fichtler et al. 2004; Brienen and Zuidema 2005; Schongart et al. 2006; Brienen et al. 2010) revealed that rainfall is the main determinant factor for tree growth although the effect of temperature variability was also reported in some regions. However, growth response to the climate signal is modified by tree species, provenance, competition, and site conditions, among others (Fritts 1976, pp. 14-23). Therefore, such studies need to be intensified in different regions considering various tree species, and this is important for planning and implementing restoration and sustainable management endeavors in tropical forests, particularly that of the tropical dry forests (TDFs).

In Ethiopia, successful dendrochronological studies were previously reported for different tree species (e.g. Gebrekiristos et al. 2008; Sass-Klaassen et al. 2008; Couralet et al. 2010; Tolera et al. 2013; Mokria et al. 2017). But, it was also revealed that the formation of annual rings is species-specific and the formation and distinctiveness of growth ring boundaries vary with specific environmental conditions under which a given species grows (Rozendaal and Zuidema 2011). Climate forcing of tree growth was 
also reported to vary among tree species elsewhere (Enquist and Leffler 2001; Brienen and Zuidema 2005; Couralet et al. 2010). Thus, undoubtedly, there is a need to perform thorough tests of climate-growth relations for more species and tropical forest types. It was argued that site- and species-specific studies need to be intensified to improve the network of tree-ring chronologies in the region and the country at large. Tree species suggested to produce annual growth rings in a given agro-ecology may not be annual or could be suppressed, under differing site conditions elsewhere. Accordingly, this study was initiated to further strengthen such studies in the dry Afromontane forest fragments of northern Ethiopia, with implications on their sustainable management through the provision of evidence on species-specific long-term growth dynamics and understanding their responses to various environmental conditions. The focus of this study was to first examine the presence of visible tree-rings in the main tree species of the remnant dry Afromontane forests and then analyze their responses to various climatic variables. As the study area is characterized by unimodal rainfall pattern with clear seasonality and prolonged dry season, tree growth is expected to be periodically limited by water scarcity and that the inter-annual variation in rainfall to be reflected in the chronological pattern of the tree-ring widths. The study attempted to address the following research questions: (i) is tree-ring formation annual and can tree-ring analysis be applied for studying long-term vegetation growth dynamics in the study region? (ii) is tree growth correlated with climatic variables (rainfall and temperature)? (iii) do the study species differ in their responses to the climatic variables?

\section{Materials and methods \\ Study area}

The study was conducted in Desa'a $\left(13^{\circ} 40^{\prime}\right.$ to $13^{\circ} 50^{\prime} \mathrm{N}, 39^{\circ}$ $\left.47^{\prime} \mathrm{E}\right)$ and Hugumburda $\left(12^{\circ} 38^{\prime} \mathrm{N}, 39^{\circ} 32^{\prime} \mathrm{E}\right)$ forests (Fig. 1), the two major dry Afromontane forest remnants in northern Ethiopia. These forests are mainly located along the western escarpment of the Great Rift Valley facing the Afar depression (Aynekulu 2011). The area falls in the semi-arid agro-ecological zone of Tigray region where the climate is influenced by topography and exposures to rain-bearing winds (Nyssen et al. 2005).

The regional climate shows distinct seasonality in rainfall with a unimodal pattern. The mean annual rainfall was estimated at $532 \mathrm{~mm}$ in Desa'a (Abegaz 2005) and $981 \mathrm{~mm}$ in Hugumburda (Aynekule 2011). The main rainy

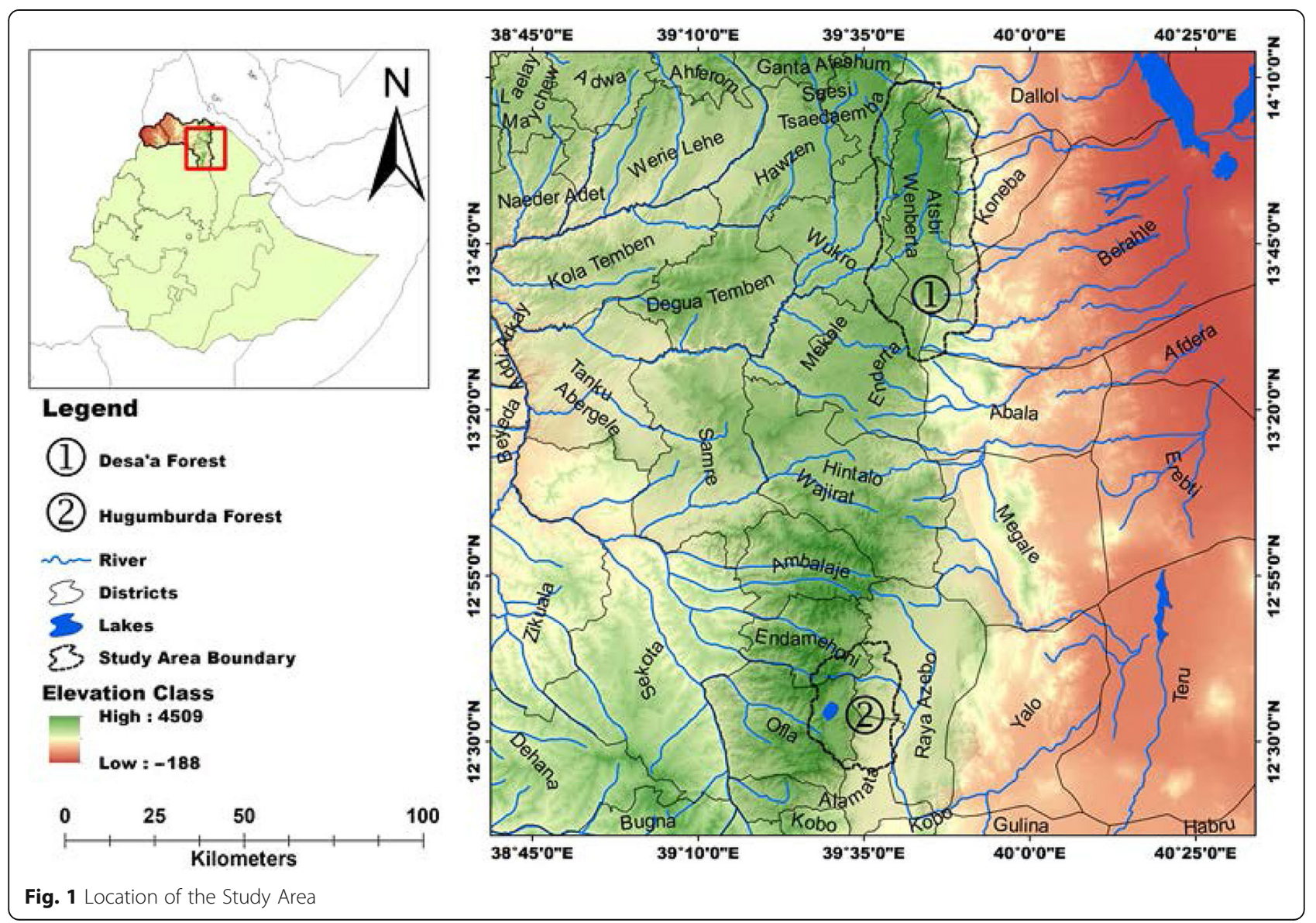


season occurs from June to September, while the remaining extended periods are more or less dry (Fig. 2).

Large areas of the forests are characterized by shallow soils and frequent rock outcrops. The dominant soil types are Leptosols, Cambisols, Vertisols, Regosols, and Arenosols (Aynekulu 2011). The study sites are generally characterized by rugged topography. These forests are broadly classified as dry Afromontane forests and are dominated by Juniperus procera and Olea europaea subsp. cuspidate.

\section{Sample collection and preparation}

Samples were taken from the main and/or co-occurring tree species in the dry Afromontane forests of Tigray region, northern Ethiopia between April and June 2017. Trees with no obvious injury or disease were carefully selected to minimize nonclimatic influences (e.g. to minimize the effect of reaction wood and wounds on the ring width patterns) on ring growth. Increment cores and/or stem discs were collected from a total of 106 trees belonging to three species, considering different diameter classes (Table 1).
For Olea europaea subsp. cuspidate, only stem discs were collected due to its dense wood. The number of stem discs was kept to a minimum to limit damage to the already threatened population of the study species. From each tree, a cross-sectional wood disc was taken with a chainsaw, and, using an increment borer, two increment core samples were collected per tree from opposite directions at breast height (approximately $1.3 \mathrm{~m}$ from the base of all trees). Taking samples from the breast height (near to breast height) is advisable because it minimizes the occurrence of wedging rings (rings that do not cover the whole circumference of the tree or that are locally absent). Wedging rings appear more frequently near the stem base (Lamarche et al. 1982). Additional information such as $\mathrm{DBH}$, location and site characteristics were also recorded during the sampling campaign. The collected samples were carefully transported to, and open air-dried at the wood-science laboratory of Wondo Genet College of Forestry and Natural Resources, Ethiopia. After air-drying, the cores and stem discs were sanded and polished progressively with finer sanding papers of grades ranging between 60 and 600 grit to improve
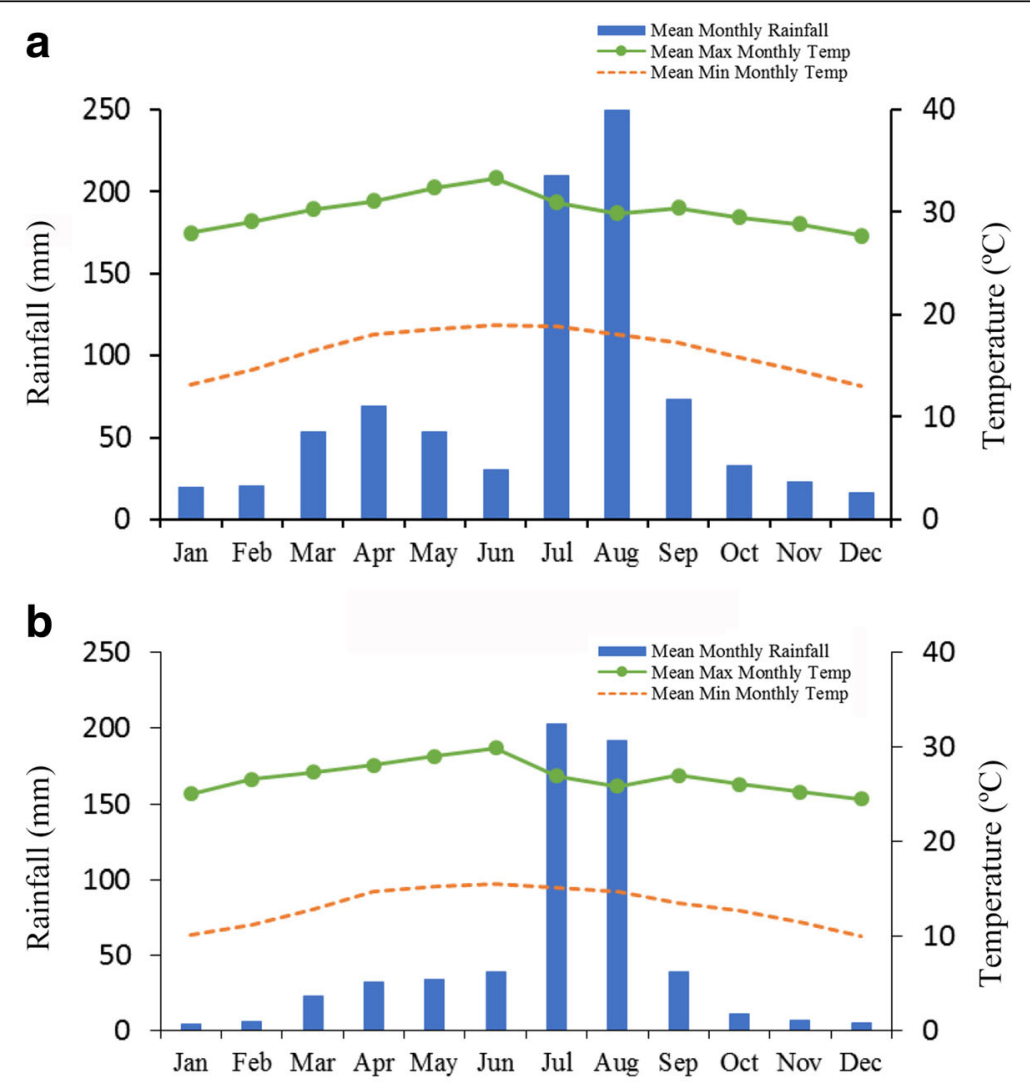

Month

Fig. 2 Mean Monthly Rainfall and Mean Monthly Temperature (Maximum and Minimum) Records (1980-2016) of the Study Areas, (a) Hugumburda and (b) Desa'a, Northern Ethiopia 
Table 1 Study species and sample size in each study site

\begin{tabular}{|c|c|c|c|c|c|c|c|}
\hline \multirow[t]{2}{*}{ Study site } & \multirow[t]{2}{*}{ Species } & \multirow[t]{2}{*}{ Family } & \multicolumn{4}{|c|}{ Sample distribution in each DBH class (cm) } & \multirow[t]{2}{*}{ Tota } \\
\hline & & & $10-15$ & $16-20$ & $21-30$ & $>30$ & \\
\hline \multirow[t]{3}{*}{ Hugumburda } & Juniperus procera & Cupressaceae & 5 & 15 & 12 & 1 & 33 \\
\hline & Olea europaea (subsp. cuspidate) & Oleaceae & 8 & 2 & 0 & 0 & 10 \\
\hline & Podocarpus falcatus & Podocarpaceae & 6 & 5 & 3 & 4 & 18 \\
\hline \multirow[t]{2}{*}{ Desa'a } & Juniperus procera & Cupressaceae & 2 & 14 & 12 & 4 & 32 \\
\hline & Olea europea & Oleaceae & 0 & 7 & 5 & 1 & 13 \\
\hline
\end{tabular}

the visibility of the growth ring boundaries and anatomical features (Fritts 1976, p 249; Schongart et al. 2006).

\section{Tree-ring measurement and crossdating}

The sanded samples were examined both macroscopically and microscopically to identify the wood anatomical features that define growth ring boundaries (Verheyden et al. 2004). Growth rings on stem discs were detected following concentric features around the stem circumference. When all rings on a disc were detected, and ring numbers and characteristics matched along different radii, ring width was measured along 3-4 radii of each stem disc. Similarly, in increment cores, rings were marked, visually compared between the two cores and then measured. All ring widths were measured to the nearest $0.001 \mathrm{~mm}$ using LEICA MS 5 microscope coupled with LINTABTM5 digital measuring stage associated to TSAP-dos software (Rinn 2003). Ring measurements were performed along predetermined radii in a straight line, and perpendicular to ring boundaries.

The resulting ring width series were visually crossdated along each radius to check for missing or wedging rings that may occur in phases of low cambial activity. Visual crossdating was undertaken with reference to pointer years (i.e., the position of very narrow or very wide rings to link rings detected on different radii). In addition to visual crossdating, all ring width series were statistically crossdated using the computer program TSAP (Time Series Analysis and Presentation) (Stokes and Smiley 1968, p 73; Cook et al. 1990). Two statistical indicators were used to evaluate the match between the time-series. These are the "Gleichläufigkeitskoeffizient" (GLK; equivalent to a sign-test) which reflects the percentage of ring width oscillations in the same direction in two-time series within a certain time period, and the " $t$-value BP" of Baillie-Pilcher (Baillie and Pilcher 1973). Mean ring width series per tree were calculated when individual series of each radius of a given tree show significant relationships, indicated by significant GLK $(p<$ 0.001 ) having a value of more than $85 \%$, and $t$-values (above 4). These statistical parameters tell us about the extent to which two curves are similar to each other and were used to select the best-correlated series (Schweingruber 1988, p 276; Fichtler et al. 2004; Worbes 2004). A similar procedure was employed to crossdate all mean ring width series for building a site chronology (Enquist and Leffler 2001). Measured and crossdated ring width series from stem discs were used as a benchmark to correctly crossdate the core samples. Samples that fail to crossdate through these stages were excluded from the subsequent analysis.

\section{Climate data}

The availability of weather stations in the study region is extremely low and the existing climate records were fragmentary (i.e., short climatic records containing missing values for several months and/or years). This imposed difficulties for understanding the temporal and spatial climate variability of the study region, which is characterized by a complex topography. Therefore, we used a combination of high-resolution climate datasets from AgMERRA (at 0.25-degree resolution) (Ruane et al. 2015) and the latest version of the Climate Research Unit time-series (CRU TS 4.01) datasets (at 0.5-degree resolution) (Mitchell and Jones 2005). These global grid datasets are widely used climate data sources in several studies, particularly in dendroclimatological studies. Especially, the climate data developed by the Climate Research Unit (CRU) of the University of East Anglia have been widely used in several studies given its global coverage, long temporal scale (since 1901) and abundance of climatic variables (Trouet and Van Oldenborgh 2013). These global grid datasets were used to derive temperature (minimum and maximum) and rainfall data, and to supplement any fragmentary climate data. The combined climate data spans the period 1901-2016. For the response analysis, climate data of the common years (1980 to 2016) were used.

\section{Data analysis}

After all ring width series were successfully crossdated, quality control was conducted using a running correlation calculated under the program COFECHA (Holmes 1983). A smoothing cubic spline (with 50\% wavelength cut-off) was fitted, in time-windows of 32 years, to the ring-series of each individual tree of all sampled species (Grissino-Mayer 2001). This procedure was employed to remove the long-term growth trends from the raw measurements and filter out low-frequency variation attributed to disturbances other than 
the common signal of interest. After fitting a cubic spline curve, residuals were calculated by dividing each raw value by the predicted value of the fitted spline.

The residual tree-ring series were compared by calculating Pearson correlations in different segment lengths, ranging between 30 and 35 years. By doing so, it was possible to detect apparent dating and measurements errors that might occur due to missing or wedging rings, which caused a shift in the tree-ring series (i.e., higher correlations of series' segments at positions other than dated). Tree-ring series that show low correlations than the critical threshold (at 99\% confidence level) provided by COFECHA were re-examined, considering recommendations on potentially missing or double rings provided by the program. Samples that failed to get fixed through this procedure were excluded from the analysis as the aim was to maximize the common signal used for building the site chronology. The main characteristics of the site chronology were summarized using descriptive statistics.

Then, species-specific tree level chronologies were established for each study site. For this purpose, individual growth ring series were detrended and standardized using the dendrochronology program library in $\mathrm{R}$ programming language (dplR) (Bunn 2008, 2010) to remove possible ontogenetic trends and low-frequency variation. The raw tree-ring series were standardized by fitting a cubic spline with the same stiffness as for the quality check (i.e., wavelength of 32 years with $50 \%$ cut-off). Detrending was used to estimate and remove the tree's natural biological growth trend. Standardization was done by dividing the original data by an estimated growth trend (estimated by the spline curve) to produce a dimensionless growth series (a stationary index series) free of autocorrelation caused by internal biological growth trends. Then, the standardized series were averaged to produce a single chronology per species in each study site. The final mean chronology of each species is a dimensionless ring width index (RWI) (with mean equal to 1 and homogeneous variance).

Climate-growth relations were examined between the indexed tree-ring series of each species and the climatic variables (rainfall and temperature) using treeclim package (in dplR). Pearson correlations were first computed to assess the relationship between the tree-ring indices and climatic variables (such as monthly and annual values of rainfall, minimum and maximum temperature, and total rainfall in distinct periods of the year). The relationships were separately tested for the climatic variables in a year, in the wet season (from Jun to September, JJAS), and at the beginning and end of the wet season. A linear regression model was established by taking ring width as the response variable and the aforementioned climate variables as explanatory variables (i.e. response function analysis). All climate variables used in the analysis were standardized in $\mathrm{R}$ (dplR packages, version
3.4.3) to avoid the inclusion of long-term trends in the climate data. Then, the periods that showed the highest relationship were shown in the result. The site chronology was also used for visual comparison with time-series of climate variables which turned out to have highly significant influences during the analysis.

\section{Results \\ Growth ring formation}

Results of the tree-ring analysis showed that all the studied tree species (J. procera, O. europaea and P. falcatus) have clearly visible rings, but the distinctiveness of the ring boundaries varied considerably with tree species and sites (Fig. 3). Such variations were also noticed within the different radii of a given sample tree. For instance, ring widths appeared to be narrower as we move towards the center and/or towards the bark, or during periods of growth suppression (i.e. during low cambial activity).

J. procera trees showed more distinct growth ring boundaries, and are demarcated by the large, round and thin-walled tracheids in earlywood and the small, flattened and thick-walled tracheids in the latewood, which run around the circumference of the stem discs. Similarly, P. falcatus also formed distinct ring boundaries, which are characterized by narrow bands of tracheids with slightly thickened cell walls towards the latewood. In O. europaea, the thick-walled vessels are surrounded by scanty (marginal) parenchyma cells and appeared less distinct compared to the other species. In some cases, wedging rings existed in all of the studied trees particularly along the shorter radii and were more apparent on $O$. europaea. The occurrence of wedging and intra-annual growth rings (false rings) were analyzed by matching them against several radii on each stem disc (i.e. visual crossdating). Attributed to various environmental factors (e.g. the stand level growing conditions), ring widths of the studied tree species showed considerable variations, ranging from extremely narrow to wider rings. Variations in tree-ring widths were observed within tree species (among the different radii) and among tree species. This variation was also noticed across the study sites. The studied tree species from Hugumburda site, which is characterized by a relatively moist climatic zone, showed visibly larger growth rings than those in Desa'a site.

In any case, identification of tree-ring boundaries and the wedging ring was easier on stem discs than core samples and thus was used to assist identification and marking of rings in core samples. Tree species with clear and concentric bands (e.g. in $J$. procera) were easily identified and marked than those trees marked by thick-walled vessels (e.g. Olea europaea). 

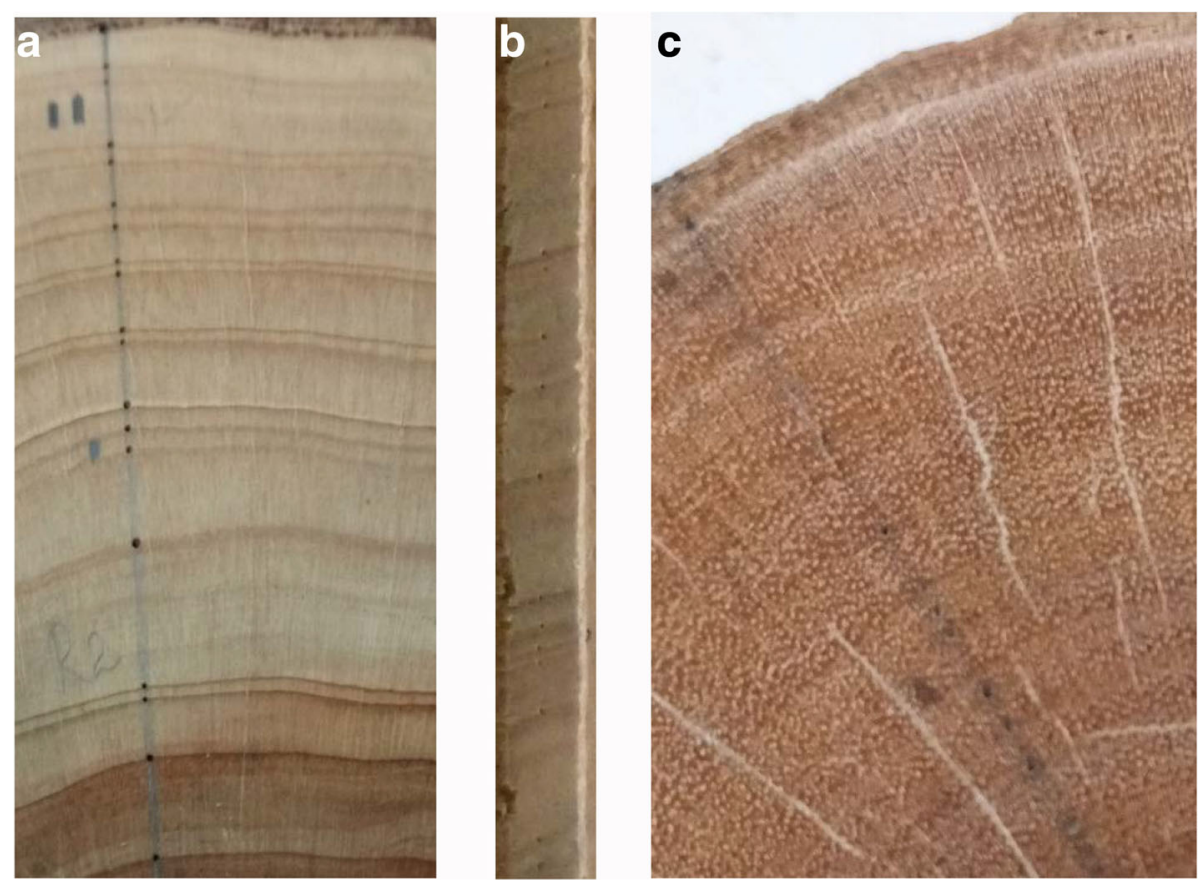

Fig. 3 Macroscopic view of growth ring boundaries of the sampled tree species; (a) J. procera, (b) P. falcatus, and (c) O. europaea. Dots indicate the growth ring boundaries

\section{Crossdating and chronology development}

All the ring width series obtained were visually and statistically crossdated and checked for their quality using the program COFECHA. Summary of the descriptive statistics of raw crossdated ring width series for the sampled species in each site is presented in Table 2.
Crossdating among the ring width series of different radii of a given tree was successful (GLK $>85 \%, p<0.001$; $t$-values $>4$ ) for all studied tree species. However, crossdating of mean ring width series of different trees was challenging particularly for slow-growing tree species, such as O. europaea, which showed considerable variations in the distinctiveness of growth ring boundaries

Table 2 Descriptive statistics of raw crossdated ring width series for the study species in each site; $t$-value BP: $t$-value Baillie Pilcher, GLK: Gleichläufigkeitskoeffizient

\begin{tabular}{|c|c|c|c|c|c|}
\hline \multirow[t]{3}{*}{ Variables } & \multicolumn{5}{|c|}{ Mean statistical attributes (or ranges) } \\
\hline & \multicolumn{3}{|c|}{ Hugumburda } & \multicolumn{2}{|l|}{ Desa'a } \\
\hline & J. procera & O. europaea & P. falcatus & J. procera & O. europaea \\
\hline No. of trees sampled & 38 & 10 & 20 & 36 & 14 \\
\hline No. of dated series & 33 & 10 & 18 & 32 & 13 \\
\hline Average diameter (cm) (range) & $20(12-42)$ & $13(10-19)$ & $21(11-39)$ & $23(14-50)$ & $22(16-35)$ \\
\hline Average age (years) (range) & $43(23-65)$ & $36(28-46)$ & $35(20-54)$ & $54(32-112)$ & $76(48-129)$ \\
\hline Time span (years) & 1949-2016 & 1969-2015 & 1963-2016 & 1905-2016 & $1888-2016$ \\
\hline Average ring width (mm) (SD) & $2.31(0.54)$ & $2.01(0.36)$ & $2.50(0.58)$ & $1.83(0.57)$ & $1.61(0.20)$ \\
\hline Average correlation with master & 0.51 & 0.54 & 0.54 & 0.57 & 0.55 \\
\hline 1st order autocorrelation (unfiltered) & 0.04 & 0.11 & 0.11 & 0.20 & 0.14 \\
\hline Average mean sensitivity & 0.63 & 0.52 & 0.52 & 0.55 & 0.43 \\
\hline Standard deviation (filtered) & 0.64 & 0.66 & 0.66 & 0.64 & 0.59 \\
\hline Flagged segments (\%) & 4.11 & 10 & 5.71 & 1.74 & 0.0 \\
\hline$t$-value BP (SD) & $5.64(1.33)$ & $7.62(1.27)$ & $6.87(2.0)$ & 7.7 (3.0) & $10.8(3.61)$ \\
\hline GLK (SD, \%) & $95.5(3.26)$ & $98.3(1.95)$ & $94(5.46)$ & $93.7(3.42)$ & $94.1(3.23)$ \\
\hline
\end{tabular}


ranging from extremely narrower to wider ring widths. Tree samples which showed higher intra-annual growth and/or wedging rings failed to crossdate successfully. In such cases, the ring width series which showed low correlations than the critical threshold (at 99\% confidence level) provided by COFECHA were re-examined, as per the recommendations provided by COFECHA, and were corrected accordingly. But, samples that failed to get fixed through this procedure were excluded from further analysis as the intention was to maximize the common signal of the series such that a site chronology can be developed.

Finally, out of the total 118 sampled trees, we were able to synchronize ring width series of 106 trees (Table 2), which showed significant correlations with their respective master chronologies (Pearson correlation, $r>0.42$ ). The average inter-serial correlation coefficients ranged from 0.48 to 0.56 in Desa'a and 0.42 to 0.59 in Hugumburda for J. procera; 0.53 to 0.57 in Desa'a and 0.46 to 0.59 in Hugumburda for O. europaea; and 0.49 to 0.56 for P. falcatus in Hugumburda. This is indicative of the quality of crossdating among the tree-ring series, and therefore there is a common environmental signal which drives tree growth in the region.

But, the ring width patterns of sample trees showed considerable variations with species and sites. The low correlations for the common periods suggest that the habitats in the dry Afromontane forest fragments are heterogeneous. Thus, the successfully crossdated ring width series were averaged into five species chronologies (Figs. 4 and 5).

The longest tree-chronology, spanning from 1888 to 2016, was observed for O. europaea from Desa'a site, followed by that of $J$. procera from the same site which covered from 1905 to 2016. In Hugumburda site, however, the chronologies were relatively short due to the difficulties encountered to access very old trees, particularly for O. europaea and $P$. falcatus trees. It can also be noted that the chronologies for some species $(O$. europaea) are well replicated over a longer period of time (e.g. $>50 \%$ of the total samples are included from 1935 to 2016). With the other species, the chronologies are moderately replicated, with more than half of the samples representing $>50 \%$ of the time span of the chronologies (from 1974 to 2016, and 1966-2016 for J. procera from Hugumburda and Desa'a sites, respectively; from 1981 to 2015 for O. europaea from Hugumburda; and from 1982 to 2016 for P. falcatus).

All five chronologies showed high year-to-year variability and common environmental signal as clearly indicated by the high values of mean sensitivity $(0.43-0.63)$, standard deviation $(0.59-0.66)$, series intercorrelation (0.51-0.57), and low values of average autocorrelation (0.04-0.20). The EPS (Expressed Population Signal) value for the study species ranged between 0.87 ( $O$. europaea) and 0.93 (J. procera), indicating the statistical quality of the mean site chronologies.

\section{Climate-growth relationships}

This study examined the relationships between the indexed tree-ring series produced for each species and the climatic variables (rainfall and temperature) at different periods of a year. Results of the climate-growth analyses which showed the highest correlations (i.e. with rainfall sums at distinct periods) are presented in Table 3 and Fig. 6 . The correlations were positive and significant when the tree-ring chronologies were compared with annual rainfall and rainfall at the main growing season (i.e. June-September, JJAS) (Table 3). However, all the correlations with rainfall of individual months in the entire year were not positive and significant. For O. europaea and $P$. falcatus, negative correlations were also noticed at the beginning of the growing season (June). All other correlations with annual rainfall and rainfall during distinct periods within the wet season were positive for all the studied species.

On the other hand, the correlations between the chronologies and temperature (minimum and maximum temperatures) were weak, alternating between positive and negative relations across the study species and sites. For J. procera in Desa'a site, however, negative and significant correlations were observed with minimum temperatures (Fig. 6).

For each species, rainfall during the period of the highest correlation (cf. Table 3) with their standardized ring widths was further analyzed using simple linear regression model. The results are shown in the scatter plots, along with the estimated linear relations, shown in Fig. 7, and confirmed a positive and linear relationship between rainfall at the specified period (annual and wet season) and tree growth.

\section{Discussion}

\section{Ring formation in the study species}

As evinced from the macroscopic and microscopic examinations, all the studied tree species exhibited clear growth ring boundaries although the degree of distinctiveness varies across species and study sites. Such variations in the distinctiveness of growth rings among the study species are attributed to differences in wood structures, which are known to be species-specific as revealed by Detienne (1989) and Worbes (1995). Moreover, it was believed that the varied site conditions and disturbance factors contributed to this disparity by acting on tree growth.

The growth boundaries in J. procera, which are characterized by the alternating thin- and thick-walled tracheids (cf. Sass-Klaassen et al. 2008; Wils et al. 2011a), are clear and were identified easily; while those of O. europaea, which consisted of scanty (marginal) parenchyma bands with thick-walled fiber, are less distinct compared to the other species, thus were more difficult to distinguish. The results are in line with previous studies elsewhere in Ethiopia which found clearly visible annual growth rings for different tree species. For J. procera trees, the formation of distinct annual growth rings was previously revealed in areas with distinct 

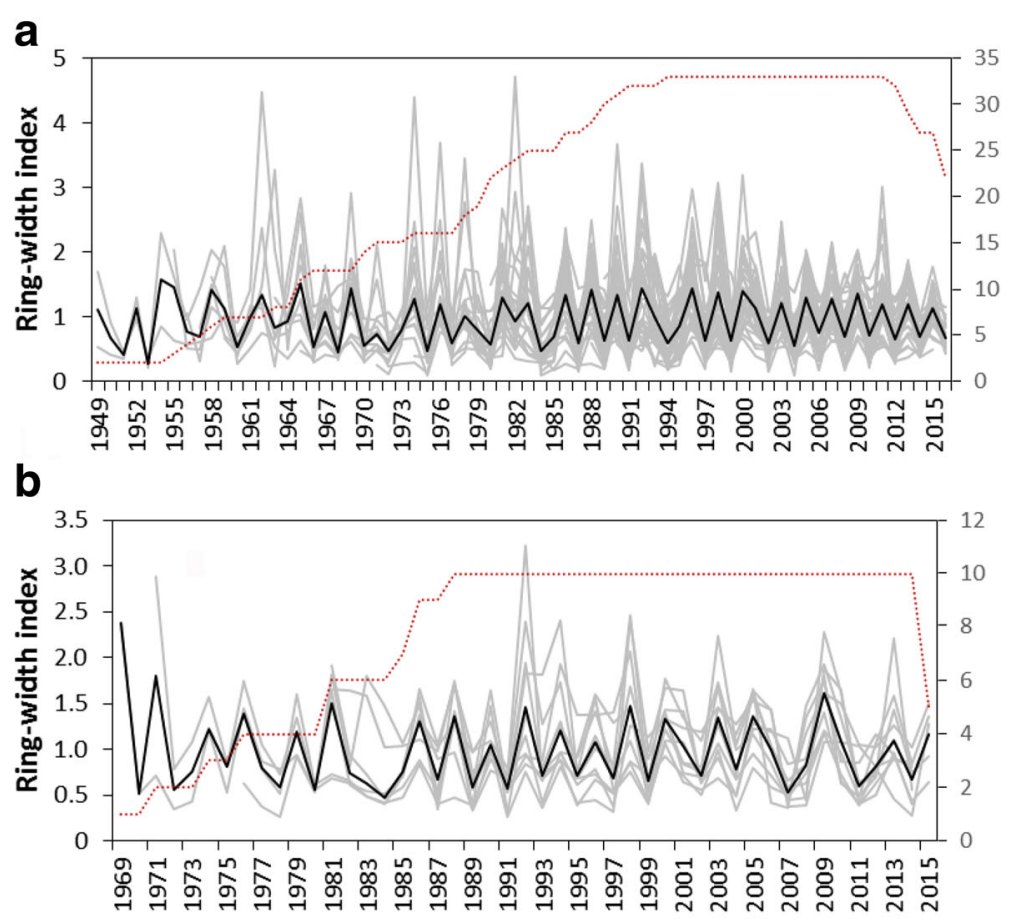

C

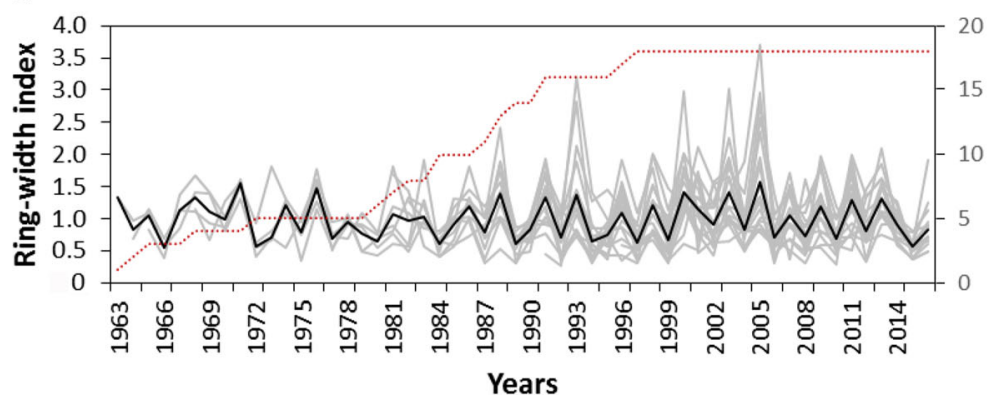

Fig. 4 The tree chronology (bold dark) and individual ring width index of crossdated tree-ring series (gray) of the study species, (a) J. procera, (b) O. europaea, and (c) P. falcatus, from the remnant dry Afromontane forest in Hugumburda, northern Ethiopia; the dashed lines indicate the sample depth (number of tree-ring series)

cycles of wet and dry seasons (Wils et al. 2011b; Couralet et al. 2005; Sass-Klaassen et al. 2008). However, considerable variations were noticed depending on the site and climate conditions where the species grows; it was even reported that J. procera trees form indistinct and non-annual growth rings in some areas in Ethiopia (Wils et al. 2009) and in Kenya (Jacoby 1989) depending on the environment where the species grows (e.g. in well-drained environment).

Similarly, the growth ring boundaries of $P$. falcatus consists of radially aligned narrow and flattened tracheids, with slightly thickened cell walls in the latewood cells. The cambial activity of the evergreen $P$. falcatus trees was previously studied in a relatively moist dry Afromontane forests in Ethiopia and revealed the occurrence of intra-annual growth resembling the annual growth rings following the onset of intra-annual climatic conditions (Krepkowski et al. 2011). This phenomenon makes the identification of the annual growth ring boundaries more challenging. The study also indicated that the occurrence of such false rings is irregular and shows considerable variation among individual trees depending on the changes in the microenvironment, thus alerted the need for further analysis to proof the annual nature of the rings. In this case, given the area is subject to extended dry periods with a relatively distinct cycle between dry and wet seasons, it was possible to identify the annual growth ring boundaries. For O. europaea, as to the knowledge of the researcher, no documentation on its dendrochronological study was found in Ethiopia.

In general, while the formation of distinct growth ring boundaries is reported hitherto, their annual nature varies considerably with different agro-ecology, thus urges for intensification and replication of such studies at different ranges of the growing limits of these tree species. The formation of distinct and annual growth rings, but 

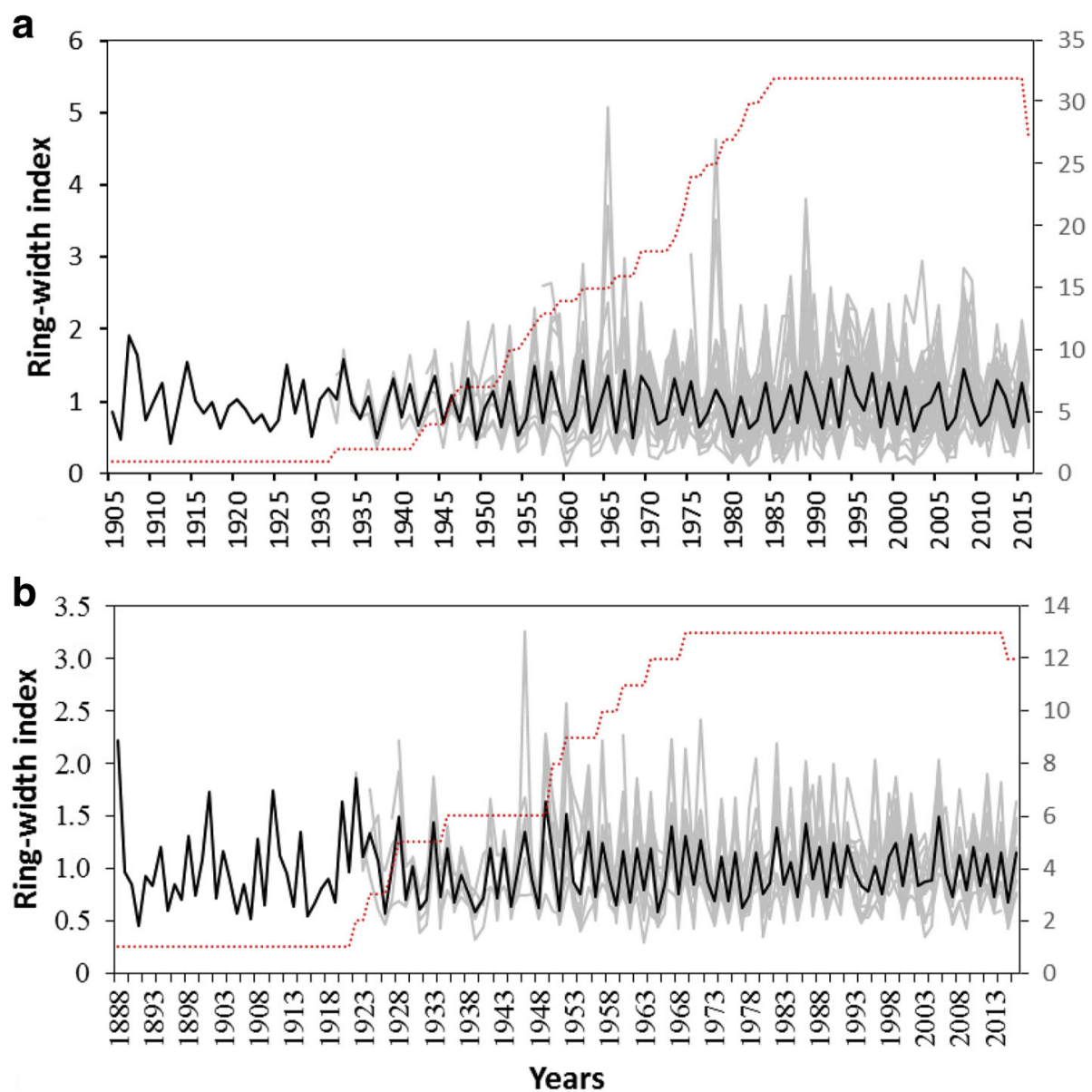

Fig. 5 The tree chronology (bold dark) and individual ring width index of crossdated tree-ring series (gray) of the study species, (a) J. procera and (b) O. europaea, from the remnant dry Afromontane forest in Desa'a, northern Ethiopia; the dashed lines indicate the sample depth (number of tree-ring series)

with varying degree of distinctiveness among species, was also reported for various other tree species in Ethiopia (Gebrekirstos et al. 2008; Couralet et al. 2010; Tolera et al. 2013) and elsewhere in the dry tropics (e.g. Rozendaal and Zuidema 2011), even in the moist tropical regions (Brienen and Zuidema 2005; Groenendijk et al. 2014). The formation of annually resolved growth rings in the tropics is most often attributed to the seasonality in rainfall (Worbes 1995, 1999).
Alike to many other dendrochronological studies of tropical tree species, this study confronted problems associated with the occurrence of intra-annual growth zones (false rings) and wedging or missing rings. In many tropical species, the existence of false and wedging rings hampered tree-ring analyses (Worbes 2002). Trees growing in harsh environmental conditions are often prone to develop multiple missing rings (Wils et al. 2011a). In this study, such anomalies were especially apparent in slow growth phases (suppression periods -which

Table 3 Pearson correlation coefficients for the relations between the ring width indices and total rainfall during distinct periods in a year with significant levels indicated (ns, non-significant; ${ }^{*}, 0.01<p<0.05 ;{ }^{* *}, 0.001<p<0.01 ;{ }^{* *}, p<0.001$ )

\begin{tabular}{|c|c|c|c|c|c|c|}
\hline \multirow[t]{2}{*}{ Site } & \multirow[t]{2}{*}{ Species } & \multicolumn{5}{|c|}{ Correlations during distinct periods in a year } \\
\hline & & Annual & Beginning of wet season & Middle of wet season & End of wet season & Entire wet season (JJAS) \\
\hline \multirow[t]{3}{*}{ Hugumburda } & J. procera & $0.59^{* * *}$ & $0.07^{\mathrm{ns}}$ & $0.55^{* * *}$ & $0.14^{\mathrm{ns}}$ & $0.56^{* * *}$ \\
\hline & O. europaea & $0.34^{*}$ & $-0.19^{\mathrm{ns}}$ & $0.44^{* *}$ & $0.32^{\text {ns }}$ & $0.43^{* *}$ \\
\hline & P. falcatus & $0.52^{* * *}$ & $-0.04^{\mathrm{ns}}$ & $0.51^{* *}$ & $0.02^{\mathrm{ns}}$ & $0.46^{* *}$ \\
\hline \multirow[t]{2}{*}{ Desa'a } & J. procera & $0.22^{\mathrm{ns}}$ & $0.17^{\mathrm{ns}}$ & $0.31^{\mathrm{ns}}$ & $0.15^{\mathrm{ns}}$ & $0.36^{*}$ \\
\hline & O. europaea & $0.35^{*}$ & $0.04^{\text {ns }}$ & $0.29^{\mathrm{ns}}$ & $0.02^{\text {ns }}$ & $0.29^{\mathrm{ns}}$ \\
\hline
\end{tabular}



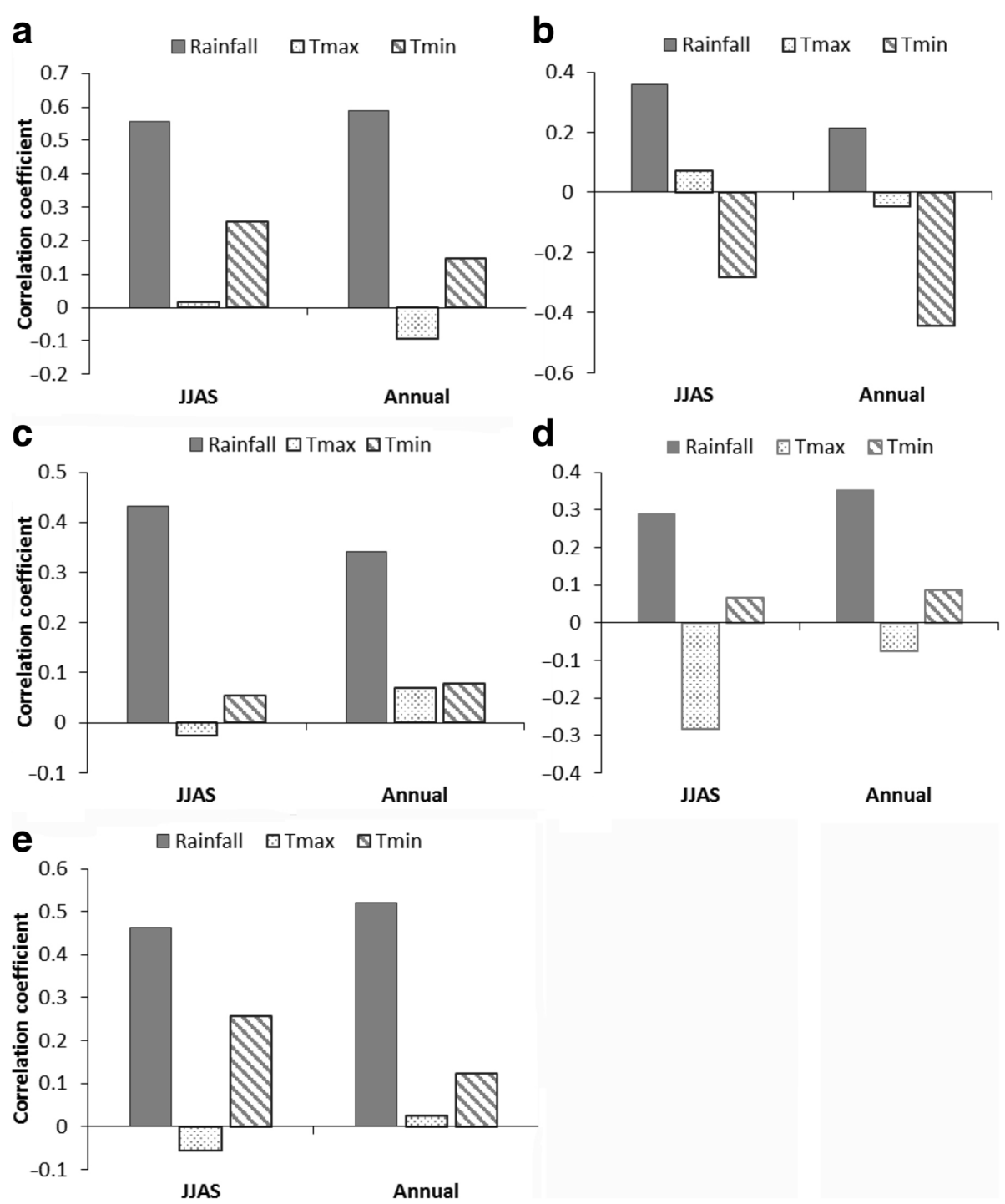

Fig. 6 Correlations between rainfall $(\mathrm{mm})$ (annual and during June-September, JJAS) and tree-ring indices, and temperature $\left({ }^{\circ} \mathrm{C}\right)(\mathrm{minimum}$ and maximum) and ring indices for the study species in both sites; J. procera from Hugumburda (a) and Desa'a (b), O. europaea from Hugumburda (c) and Desa'a (d), and P. falcatus from Hugumburda (e)

are induced by various growth limiting factors), and with narrower rings and eccentric growth as shown with some stem discs. Slow growing trees such as O. europaea trees, were associated with such anomalies and affected the accuracy of growth ring identification. However, such problems were minimized by matching the growth ring boundaries across different radii and by checking their continuity over the entire circumference of a stem disc. Previous works also highlighted the necessity of working with entire stem discs to increase dating accuracy and to address anatomical differences between annual and intra-annual growth zones in tropical species (Worbes 1995; Worbes 2002; Brienen and Zuidema 2005).

In this study, higher values of inter-series correlations and mean sensitivity were found for all studied species across sites. These higher values of inter-series correlations and mean sensitivity (Stahle 1999) coupled with the significant correlations of ring widths with rainfall confirm that the rings were formed annually (Brienen and Zuidema 2005; Brienen et al. 2016). Several other studies on tropical tree species also used successful crossdating (Worbes 1995; Stahle et al. 1999; Worbes et al. 2003; Fichtler et al. 2004; Gaspard et al. 2018) and correlations between tree-ring chronologies and rainfall (Worbes 1999; Fichtler et al. 2004; Brienen and Zuidema 2005; Couralet et al. 2005; Baker et al. 2008; Brienen et al. 2016) as a proof for the formation of annual growth rings for various tree species.

Therefore, as expected, the unimodal rainfall pattern coupled with the extended dry periods induce cambial dormancy during the dry periods followed by active growth during the wet seasons, thus forming annually-resolved growth 

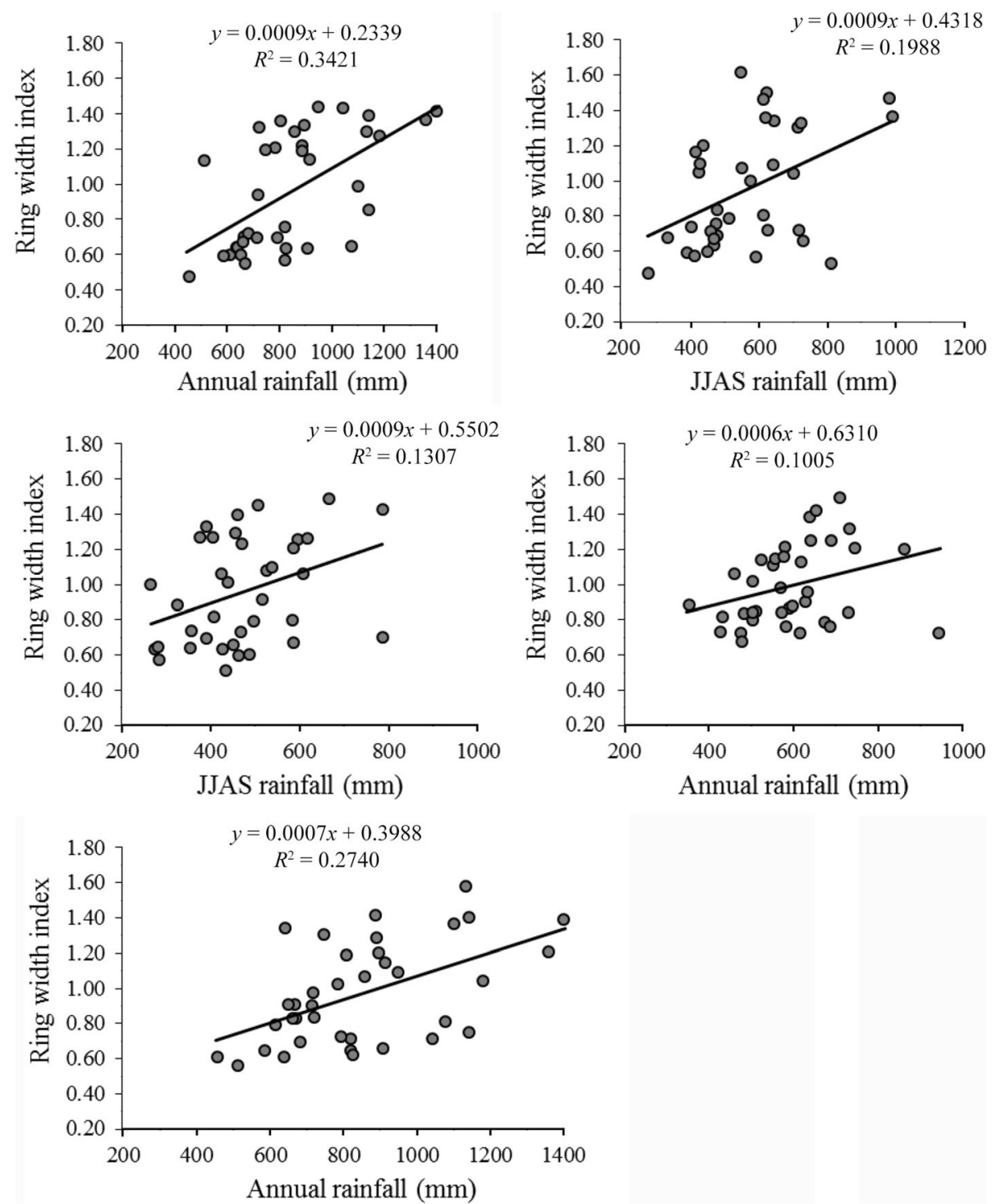

Fig. 7 Scatter diagram of relationships between rainfall (annual and wet season) and tree-ring indices of the study species in each site for a common period (1980-2016)

rings. Results of this study agree with previous studies showing that many tropical species are characterized by distinct seasonal patterns of radial growth. This seasonality and the long dry season particularly in water-deficit forest ecosystems induces periodic cambial dormancy in trees, leading to the formation of annual growth rings (Worbes 1999; Schongart et al. 2006; Gebrekirstos et al. 2008; Sheffer et al. 2011).

\section{Crossdating}

Overall, crossdating among trees was successful for each tree species in both study sites. Samples which failed to match with the rest of the ring width series, probably due to the high incidence of false, wedging, and/or missing rings were excluded to minimize dating errors which may compromise the master chronology. Thence, successfully crossdated ring width series which showed higher inter-series correlations were used to establish tree-ring chronologies for the study species. Other studies conducted in a similar environment in Ethiopia also reported successful crossdating for J. procera trees (Couralet et al. 2005; Sass-Klaassen et al. 2008; Wils et al. 2011b) and other tree species from the dry forests and woodlands belonging to the genera Acacia (Eshete and Ståhl 1999; Gebrekirstos et al. 2008) and Boswellia (Tolera et al. 2013; Mokuria et al. 2017).

Although it varies among species and regions, a series intercorrelation value of about 0.4 is, generally, considered crossdatable (Fritts 1976, p 254-268). In this study, high values of mean sensitivity (0.43-0.63), standard deviation (0.59-0.66), series intercorrelation (0.51-0.57), and low values of average autocorrelation $(0.04-0.20)$ were found. All 
the inter-serial correlations calculated in COFECHA were greater than their respective critical levels $(p<0.001)$ for all study species, implying that the statistical crossdating for all study species is highly significant.

Several other studies, particularly from the dry tropical regions found similar higher values of mean sensitivity and inter-series correlations and revealed their significance for tree-ring studies in the tropics. These site- and species-specific mean inter-series correlations are generally comparable (e.g. Wils et al. 2011a) reported it to be $0.52-0.59$ for $J$. procera trees sampled from North Gondar, Ethiopia or within the range of other similar studies reported for various tropical tree species elsewhere, which ranges from 0.24 (Trouet et al. 2006) to 0.63 (Therrell et al. 2006). The average mean sensitivity values reported here are also comparable or higher than those reported by several authors elsewhere; for instance, an average mean sensitivity value in the ranges of $0.25-0.50$ was reported for $J$. procera from Ethiopia (Wils et al. 2011b); 0.39-0.49 for Brachystegia spiciformis Benth. From Zambia (Trouet et al. 2006), 0.420.50 for three understory tree species from the Democratic Republic of Congo (Couralet et al. 2010); and 0.27-0.29 for Burkea africana Hook and 0.31-0.41 for Pterocarpus angolensis D.C. from Namibia (Fichtler et al. 2004).

These statistical attributes of the tree-ring chronologies, such as high inter-series correlations (Stahle 1999) and high mean sensitivity values show that the chronologies are sensitive to climate variability ( $\mathrm{He}$ et al. 2013). The higher year-to-year variability, expressed as mean sensitivity (Fritts 1976, p 261) together with low values of autocorrelation indicates strong responses to annually changing environmental conditions (Sass-Klaassen et al. 2008). This is indicative for the synchronous growth patterns among individual trees of a given species, and that the studied tree species respond to a common climate forcing which corresponds with periodic wood formation among the trees (Worbes 1995). Similar to this study region, such strong inter-annual variability of tree-ring chronologies is typical of moisturesensitive regions (Fritts et al. 1980), indicating that the chronologies developed from the study species have captured strong common climate signals. Besides, the study species showed an EPS value higher than the threshold value (FPS $>0.85$ ) suggested by Wigley et al. (1984) for the reliability of chronology development. These results confirm that trees of the same species synchronize their growth in response to a common environmental factor, providing further proof for the applicability of dendrochronological studies in the study region. Thus, these tree-ring chronologies are believed to provide useful climate proxy data to study regional climate variations in the region and to study the large-scale climate system. In general, the study confirms the potential suitability of tree-ring data from the study region as a proxy for further dendroecological and paleoclimate studies in the region.

\section{Climate-growth relations}

All the study species from the remnant dry Afromontane forests of northern Ethiopia showed positive and significant relationships with rainfall of the main growing season (JJAS) and annual rainfall. This supports the claim that plant growth in dry regions is more likely related to the total available soil moisture than water availability during specific periods, and thus the soil-plant system is buffered at seasonal rather than monthly timescales (Krepkowski et al. 2011). This can be ascribed to the phenological characteristics of the evergreen tree species, which are known to radially grow under sufficient soil moisture conditions.

The formation of distinct annual growth rings in the study species is also an indication of a common climate forcing of tree growth, i.e., the rainfall seasonality which is characterized by a unimodal pattern. This signifies the detrimental role of moisture availability for tree growth.

The strong relations of the tree-ring chronologies with wet-season rainfall is illustrated by a highly synchronous pattern between growth and rainfall in Fig. 8 using part chronologies from J. procera as an example.

The finding of this study agrees with Krepkowski et al. (2011) and Brienen et al. (2016) who found that tropical tree growth is sensitive to the amount of rainfall received. Other similar tree-ring studies from the seasonally dry tropical regions also found tree growth to be positively influenced by rainfall seasonality (Gebrekirstos et al. 2008, Couralet 2010). This positive relationship implies that rainfall is an overriding climatic factor determining plant growth in the study region. Some dendrochronological studies conducted elsewhere in the tropics have also shown that tree growth is influenced by rainfall seasonality in areas with rainfall amount ranging between 1000 and $1700 \mathrm{~mm}$ (Worbes 1999; Stahle et al. 1999; Enquist and Leffler 2001). In view of this, the fact that the amount of rainfall in our study sites is generally below 1000 $\mathrm{mm}$ signifies that plant growth is highly limited by water-deficit conditions in the study region.

In agreement with some findings of previous tree-ring studies elsewhere in Africa (e.g. Fichtler et al. 2004; Gebrekirstos et al. 2008; Trouet et al. 2010), in this study, the major seasonal precipitation displayed higher regression coefficient values with ring growth compared to annual precipitation (Fig. 7). Strong correlations of tree growth with rainfall during the main rainy season were reported not only for deciduous trees but also for many evergreen tropical tree species (Worbes 1999; Enquist and Leffler 2001; Fichtler et al. 2003; Gebrekirstos et al. 2008). A strong wet-season impact on tree growth is expected as $90 \%$ of the annual rainfall in most dry tropical regions falls during that season (Brienen et al. 2010). Trouet et al. (2010) also reported the influence of climate, and of precipitation in particular, on tree growth to be strongest at the core of the rainy season. 
In this study, the overall pattern of tree species' sensitivity to rainfall was found to be more or less similar. Strong correlations with rainfall occurred during the mid-rainy season (July-August), whereas no significant effects of rainfall were observed in the beginning and end of the wet season. This finding is partially comparable to that reported by Brienen and Zuidema (2005), who found the highest sensitivity to rainfall early in the rainy season but insignificant effect of rain late in the season. The authors argued such sensitivity patterns to comply with the early saturation of the soil water reserves which are then retained within the entire season, entailing that there is more significance of rainfall at the beginning of the rainy season than at the end. Unlike this explanation, in this case, it is believed that the small amount of rainfall during the beginning of the rainy season is not sufficient to break the extended dormancy period, but as the rainy season proceeds, the continued enrichment of soil water can significantly enhance radial growth. But then, it shortly becomes limited towards the end of the wet season, making it less significant for tree growth again. Therefore, it seems plausible that the available amount of water during the mid-wet season largely determines tree growth in the study region. The observed variation in the strength of relationships of tree growth and rainfall across species may be explained in relation to the ontogenetic (physiological responses) and site condition (other related environmental factors) differences and the interactions thereof. Such differential growth responses may be linked to functional traits related to water storage and conductance (Mendivelso et al. 2013).

Besides, this study also recognized correlations with minimum and maximum temperatures although they were largely insignificant, alternating between positive and negative relationships. In this way, it can be inferred that temperature has some degree of influence on the growth of the tree species, but was generally complex and weak.

\section{a}

Rainfall of wet season

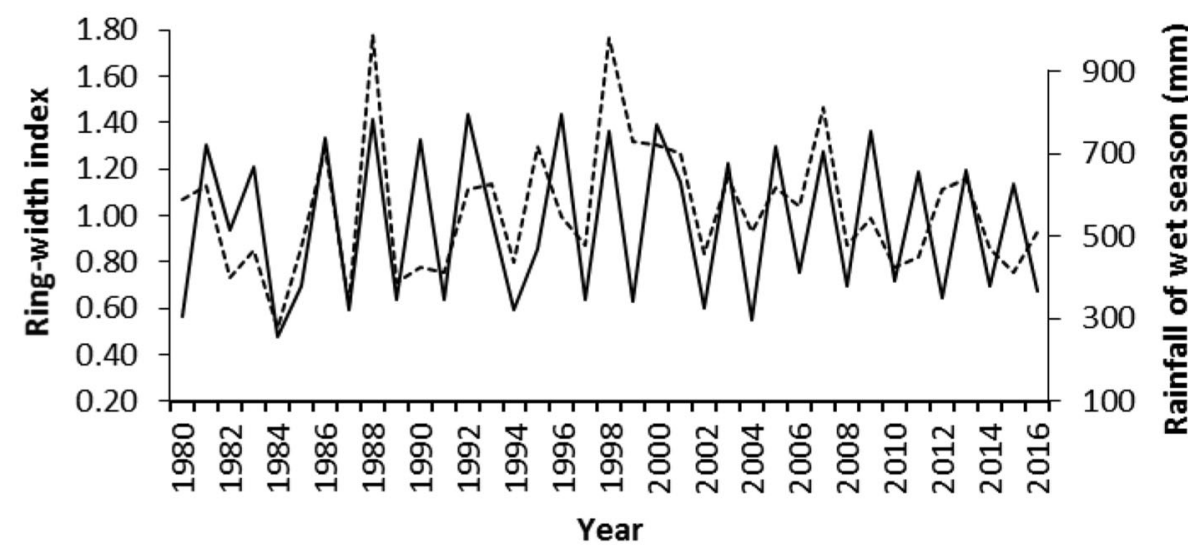

b - Ring-width index Rainfall of wet season

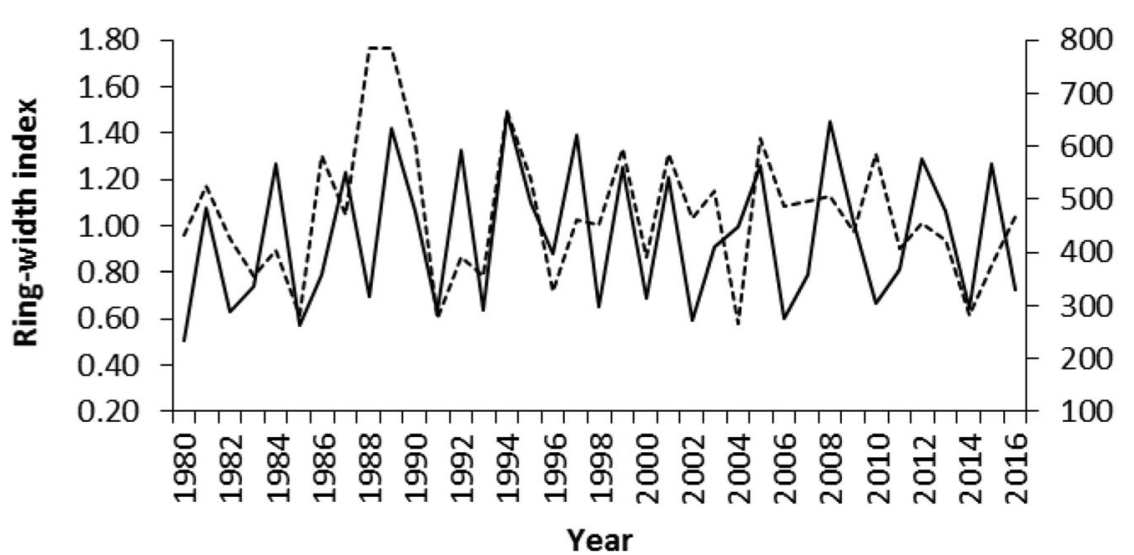

हี

Fig. 8 Visual comparison of rainfall during the wet season (JJAS) and part of the chronology for J. procera from the two study sites, Hugumburda (a) and Desa'a (b), as an example to show the synchrony between tree growth and rainfall 
Negative relationships between tree growth and temperature were also reported in other seasonally dry tropical regions (Schongart et al. 2006; Gebrekirstos et al. 2008; PuchaCofrep et al. 2015; Mokria et al. 2017). The negative relations between temperature and the chronologies implies that high temperatures may negatively affect tree growth, possibly by increasing drought stress due to the enhanced evapotranspiration losses.

In general, studies undertaken in the dry tropics have highlighted the influence of climate on tree growth. These studies revealed that tree growth is significantly correlated predominantly with rainfall seasonality (Bullock 1997; Stahle et al. 1999; Worbes 1999; Fichtler et al. 2004; Therrell et al. 2006; Nath et al. 2006; Schongart et al. 2006; Gebrekirstos et al. 2008; Brienen et al. 2010) in most of these regions, and also with temperature variability in others (Fichtler et al. 2004; Trouet et al. 2006). This implies that climate signal is one of the main controlling factors for tree growth in tropical regions. However, growth response to the climate signal is modified by tree species, provenance, competition and site conditions, among others as revealed by Fritts (1976). Therefore, such studies need to be intensified in different regions considering various tree species, and this is important for planning and implementing restoration and sustainable management endeavors in tropical forests, particularly that of the TDFs.

\section{Conclusions}

This study found anatomically distinct annual growth rings and statistically validated cross-dating. The study species were generally responsive to the seasonal rainfall availability, particularly to the moisture during the core rainy season, and the climate signals recorded in our study species revealed a general coherence with several other climate-growth analyses in Ethiopia and elsewhere in the tropics. Although the strength of correlations was found to vary among the studied tree species, overall, across species and sites, the relations between rainfall and tree growth were positive. The relations with ring widths were particularly significant when compared with rainfall during the core rainy season (JJAS). But, the correlations with temperature (both minimum and maximum temperatures) ranged from positive to negative at certain periods of the year though they were weak. This implies that rainfall remains the major climatic driver of plant growth in the dry Afromontane forest fragments of northern Ethiopia. At certain times, temperature, by contributing to the high evapotranspiration losses, may also affect plant growth negatively. However, differential growth responses to rainfall were observed among the studied tree species and between study sites, implying that the common climate forcing may be combined with effects emanating from ontogenetic and site condition differences (e.g. status of soil nutrients, soil water holding capacities and tree's water uptake capabilities).
The results also showed that trees of the same species synchronize their growth in response to the common climate signal, providing further proof for the applicability of dendrochronological studies in the study region. Therefore, tree-ring data from the region can serve as a proxy for further dendroecological and paleoclimate studies. But, this has to be supported by further eco-physiological studies to further understand the responses of these and related main species to the varied environmental gradients to better explain the dynamics in relation to emerging environmental changes.

\section{Abbreviations}

dpIR: dendrochronology program library in R programming language; RWI: Ring width index; TDFs: Tropical Dry Forests; TSAP: Time Series Analysis and Presentation

\section{Acknowledgments \\ The authors are grateful to the Pan African University (PAU), African Union $(\mathrm{AU})$, Addis Ababa, Ethiopia for the financial support for this study. The authors would like to extend their gratefulness to all individuals who contributed for the successful accomplishment of this study. We also thank anonymous reviewers for their comments and suggestions.}

\section{Funding}

The financial supports for this study were obtained from the Pan African University (PAU), African Union (AU), Addis Ababa, Ethiopia as part of its PhD scholarship scheme.

Availability of data and materials

Data will not be shared until the ongoing PhD project under the Pan African University is accomplished.

\section{Authors' contributions}

ZG conceived and designed the methods, selected materials, carried out the data collection and analyzed data, and prepared the manuscript. JOA, MAO and MT provided professional input in its design and helped to draft and edit the manuscript. All authors read and approved the final manuscript.

Ethics approval and consent to participate

Not applicable.

\section{Consent for publication}

Not applicable.

\section{Competing interests}

The authors declare that they have no competing interests.

\section{Author details}

${ }^{1}$ Pan African University, Life and Earth Sciences (including Health and Agriculture) Institute, University of Ibadan, Ibadan, Nigeria. ${ }^{2}$ Wondo Genet College of Forestry and Natural Resource, Hawassa University, P.O. Box 128, Shashemene, Ethiopia. ${ }^{3}$ Department of Geography, University of Ibadan, Ibadan, Nigeria. ${ }^{4}$ Department of Agricultural and Environmental Engineering, University of Ibadan, Ibadan, Nigeria.

Received: 12 November 2018 Accepted: 11 March 2019 Published online: 03 April 2019

\section{References}

Abegaz A (2005) Farm management in mixed crop-livestock systems in the northern highlands of Ethiopia. Wageningen University, Dissertation

Aynekulu E (2011) Forest diversity in fragmented landscapes of northern Ethiopia and implications for conservation. Bonn University, Dissertation

Baillie MG, Pilcher JR (1973) A simple crossdating program for tree-ring research. Tree-Ring Bull 33:7-14 
Baker PJ, Palmer JG, D'Arrigo R (2008) The dendrochronology of Callitris intratropica in northern Australia: annual ring structure, chronology development and climate correlations. Aust J Bot 56(4):311-320

Blackie R, Baldauf C, Gautier D, Gumbo D, Kassa H, Parthasarathy N, Paumgarten F, Sola P, Pulla S, Waeber P, Sunderland T (2014) Tropical dry forests: the state of global knowledge and recommendations for future research (vol 2). CIFOR, Bogor Indonesia

Bonan GB (2008) Forests and climate change: forcings, feedbacks, and the climate benefits of forests. Science 320(5882):1444-1449

Borchert R, Rivera G (2001) Photoperiodic control of seasonal development and dormancy in tropical stem-succulent trees. Tree Physiol 21(4):213-221

Brienen RJ, Schöngart J, Zuidema PA (2016) Tree rings in the tropics: insights into the ecology and climate sensitivity of tropical trees. In: Goldstein G, Santiago L (eds) Tropical tree physiology. Tree Physiology, vol 6. Springer, Cham, pp 439-461

Brienen RJ, Zuidema PA (2005) Relating tree growth to rainfall in Bolivian rain forests: a test for six species using tree ring analysis. Oecologia 146(1):1-12

Brienen RJ, Zuidema PA, Martínez-Ramos M (2010) Attaining the canopy in dry and moist tropical forests: strong differences in tree growth trajectories reflect variation in growing conditions. Oecologia 163(2):485-496

Bullock SH (1997) Effects of seasonal rainfall on radial growth in two tropical tree species. Int J Biometeorol 41(1):13-16

Bunn AG (2008) A dendrochronology program library in R (dplR). Dendrochronologia 26(2):115-124

Bunn AG (2010) Statistical and visual crossdating in $R$ using the dpIR library. Dendrochronologia 28(4):251-258

Clark DA (2007) Detecting tropical forests' responses to global climatic and atmospheric change: current challenges and a way forward. Biotropica 39(1):4-19

Cook ER (1987) The decomposition of tree-ring series for environmental studies. Tree-Ring Bull, USA

Cook ER, Briffa KR, Shiyatov S, Mazepa A, Jones PD (1990) Data analysis. In: Cook ER, Kairiukstis LA (eds) Methods of dendrochronology: applications in the environ-mental sciences. Kluwer Academic Publishers, Dordrecht, pp 97-162

Couralet C, Sass-Klaassen U, Sterck F, Bekele T, Zuidema PA (2005) Combining dendrochronology and matrix modelling in demographic studies: an evaluation for Juniperus procera in Ethiopia. Forest Ecol Manag 216(1-3):317-330

Couralet C, Sterck FJ, Sass-Klaassen U, Van Acker J, Beeckman H (2010) Speciesspecific growth responses to climate variations in understory trees of a central African rain forest. Biotropica 42(4):503-511

Détienne P (1989) Appearance and periodicity of growth rings in some tropical woods. IAWA J 10(2):123-132

Enquist BJ, Leffler AJ (2001) Long-term tree ring chronologies from sympatric tropical dry-forest trees: individualistic responses to climatic variation. J Trop Ecol 17(1):41-60

Eshete G, Ståhl G (1999) Tree rings as indicators of growth periodicity of acacias in the Rift Valley of Ethiopia. Forest Ecol Manag 116(1-3):107-117

Fichtler E, Clark DA, Worbes M (2003) Age and long-term growth of trees in an old-growth tropical rain forest, based on analyses of tree rings and $14 \mathrm{C} 1$. Biotropica 35(3):306-317

Fichtler E, Trouet V, Beeckman H, Coppin P, Worbes M (2004) Climatic signals in tree rings of Burkea africana and Pterocarpus angolensis from semiarid forests in Namibia. Trees 18(4):442-451

Fritts HC (1976) Tree ring and climate. Academic Press Inc, London, pp 1-567

Fritts HC, Lofgren GR, Gordon GA (1980) Past climate reconstructed from tree rings. J Interdisc History 10(4):773-793

Gaspard DT, Venegas-González A, Beeckman H, Randriamalala JR, Tomazello-Filho M, De Ridder M, Ramananantoandro T (2018) Tree ring responses to climate variability of xerophytic thickets from south Soalara, Madagascar. Dendrochronologia 49:57-67

Gebrekirstos A, Mitlöhner R, Teketay D, Worbes M (2008) Climate-growth relationships of the dominant tree species from semi-arid savanna woodland in Ethiopia. Trees 22(5):631-641

Grissino-Mayer HD (2001) Evaluating crossdating accuracy: a manual and tutorial for the computer program COFECHA. Tree-Ring Res 57(2):205-221

Groenendijk P, Sass-Klaassen U, Bongers F, Zuidema PA (2014) Potential of treering analysis in a wet tropical forest: a case study on 22 commercial tree species in Central Africa. Forest Ecol Manag 323:65-78

He M, Yang B, Bräuning A, Wang J, Wang Z (2013) Tree-ring derived millennial precipitation record for the south-central Tibetan plateau and its possible driving mechanism. Holocene 23(1):36-45

Holmes RL (1983) Computer-assisted quality control in tree-ring dating and measurement. Tree-Ring Bull 43(1):69-78
IPCC (2007) Climate change 2007: impacts, adaptation and vulnerability. Fourth Assessment Report, Geneva

IPCC (2013) Fourth assessment report: climate change 2013 (AR5). Intergovernmental panel on climate change, Geneva

Jacoby GC (1989) Overview of tree-ring analysis in tropical regions. lava J 10(2):99-108

Krepkowski J, Bräuning A, Gebrekirstos A, Strobl S (2011) Cambial growth dynamics and climatic control of different tree life forms in tropical mountain forest in Ethiopia. Trees 25(1):59-70

Lamarche VC, Cook ER, Baillie MGL (1982) Sampling strategies. In: Hughes MK, Kelly PM, Pilcher JR, Lamarche VC Jr (eds) Climate from tree rings. Cambridge University Press, Cambridge, pp 2-6

Lewis SL, Lloyd J, Sitch S, Mitchard ET, Laurance WF (2009) Changing ecology of tropical forests: evidence and drivers. Ann Rev Ecol Evol Syst 40:529-549

Lieberman D, Lieberman M, Hartshorn G, Peralta R (1985) Growth rates and age-size relationships of tropical wet forest trees in Costa Rica. J Trop Ecol 1(2):97-109

Mendivelso HA, Camarero JJ, Obregón OR, Gutiérrez E, Toledo M (2013) Differential growth responses to water balance of coexisting deciduous tree species are linked to wood density in a Bolivian tropical dry forest. PLoS One 8(10):e73855. https://doi.org/10.1371/journal.pone.0073855

Mitchell TD, Jones PD (2005) An improved method of constructing a database of monthly climate observations and associated high-resolution grids. Int J Climatol 25(6):693-712

Mokria M, Tolera M, Sterck FJ, Gebrekirstos A, Bongers F, Decuyper M, Sass-Klaassen U (2017) The frankincense tree Boswellia neglecta reveals high potential for restoration of woodlands in the horn of Africa. Forest Ecol Manag 385:16-24

Nath CD, Dattaraja HS, Suresh HS, Joshi NV, Sukumar R (2006) Patterns of tree growth in relation to environmental variability in the tropical dry deciduous forest at Mudumalai, southern India. J Biosci 31(5):651-669

Nyssen J, Vandenreyken H, Poesen J, Moeyersons J, Deckers J, Haile M, Salles C, Govers G (2005) Rainfall erosivity and variability in the northern Ethiopian highlands. J Hydrol 311(1):172-187

Pucha-Cofrep D, Peters T, Bräuning A (2015) Wet season precipitation during the past century reconstructed from tree-rings of a tropical dry forest in southern Ecuador. Glob Planet Change 133:65-78

Rinn F (2003) TSAP-win, software for tree-ring measurement analysis and presentation. Rinntech, Heidelberg

Rozendaal DM, Zuidema PA (2011) Dendroecology in the tropics: a review. Trees 25(1):3-16

Ruane AC, Goldberg R, Chryssanthacopoulos J (2015) Climate forcing datasets for agricultural modeling: merged products for gap-filling and historical climate series estimation. Agric For Meteorol 200:233-248

Sass-Klaassen U, Couralet C, Sahle Y, Sterck FJ (2008) Juniper from Ethiopia contains a large-scale precipitation signal. Int J Plant Sci 169(8):1057-1065

Schongart J, Orthmann B, Hennenberg KJ, Porembski S, Worbes M (2006) Climate-growth relationships of tropical tree species in West Africa and their potential for climate reconstruction. Glob Chang Biol 12(7):1139-1150

Schöngart J, Piedade MTF, Ludwigshausen S, Horna V, Worbes M (2002) Phenology and stem-growth periodicity of tree species in Amazonian floodplain forests. J Trop Ecol 18(4):581-597

Schweingruber FH (1988) Tree rings: basics and applications of dendrochronology. Kluwer Academic Publishers, Dodrecht, p 276

Sheffer E, Yizhaq H, Shachak M, Meron E (2011) Mechanisms of vegetation-ring formation in water-limited systems. J Theor Biol 273(1):138-146

Stahle DW (1999) Useful strategies for the development of tropical tree-ring chronologies. IAWA J 20(3):249-253

Stahle DW, Mushove PT, Cleaveland MK, Roig F, Haynes GA (1999) Management implications of annual growth rings in Pterocarpus angolensis from Zimbabwe. Forest Ecol Manag 124(2-3):217-229

Stokes MA, Smiley TL (1968) An introduction to tree-ring da-ting. University of Chicago Press, Chicago, p 73

Therrell MD, Stahle DW, Ries LP, Shugart HH (2006) Tree-ring reconstructed rainfall variability in Zimbabwe. Clim Dyn 26(7-8):677-685

Tolera M, Sass-Klaassen U, Eshete A, Bongers F, Sterck FJ (2013) Frankincense tree recruitment failed over the past half century. Forest Ecol Manag 304:65-72

Trouet V, Coppin P, Beeckman H (2006) Annual growth ring patterns in Brachystegia spiciformis reveal influence of precipitation on tree growth. Biotropica 38(3):375-382

Trouet V, Esper J, Beeckman H (2010) Climate/growth relationships of Brachystegia spiciformis from the miombo woodland in south Central Africa. Dendrochronologia 28(3):161-171

Trouet V, Van Oldenborgh GJ (2013) KNMI climate explorer: a web-based research tool for high-resolution paleoclimatology. Tree-Ring Res 69(1):3-13 
Verheyden A, Kairo JG, Beeckman H, Koedam N (2004) Growth rings, growth ring formation and age determination in the mangrove Rhizophora mucronata. Ann Bot 94(1):59-66

Wigley TM, Briffa KR, Jones PD (1984) On the average value of correlated time series, with applications in dendroclimatology and hydrometeorology. J Clim Appl Meteorol 23(2):201-213

Wils TH, Robertson I, Eshetu Z, Sass-Klaassen UG, Koprowski M (2009) Periodicity of growth rings in Juniperus procera from Ethiopia inferred from crossdating and radiocarbon dating. Dendrochronologia 27(1):45-58

Wils TH, Robertson I, Eshetu Z, Touchan R, Sass-Klaassen U, Koprowski M (201 1b) Crossdating Juniperus procera from North Gondar, Ethiopia. Trees 25(1):71-82

Wils THG, Sass-Klaassen UGW, Eshetu Z, Bräuning A, Gebrekirstos A, Couralet C, Robertson I, Touchan R, Koprowski M, Conway D, Briffa KR, Beeckman H (2011a) Dendrochronology in the dry tropics: the Ethiopian case. Trees 25(3):345-354

Worbes M (1995) How to measure growth dynamics in tropical trees a review. IAWA J 16(4):337-351

Worbes M (1999) Annual growth rings, rainfall-dependent growth and long-term growth patterns of tropical trees from the Caparo Forest Reserve in Venezuela. J Ecol 87(3):391-403

Worbes M (2002) One hundred years of tree-ring research in the tropics-a brief history and an outlook to future challenges. Dendrochronologia 20(1-2):217-231

Worbes M (2004) Tree-ring analysis. Encyclopedia of forest sciences. Elsevier. Holland, Amsterdam, pp 586-599

Worbes M, Staschel R, Roloff A, Junk WJ (2003) Tree ring analysis reveals age structure, dynamics and wood production of a natural forest stand in Cameroon. Forest Ecol Manag 173(1-3):105-123

Zhou X, Fu Y, Zhou L, Li B, Luo Y (2013) An imperative need for global change research in tropical forests. Tree Physiol 33(9):903-912

Zuidema PA, Baker PJ, Groenendijk P, Schippers P, van der Sleen P, Vlam M, Sterck F (2013) Tropical forests and global change: filling knowledge gaps. Trends Plant Sci 18(8):413-419

Zuidema PA, Brienen RJ, Schöngart J (2012) Tropical forest warming: looking backwards for more insights. Trends Ecol Evol 27(4):193-194

\section{Submit your manuscript to a SpringerOpen ${ }^{\circ}$ journal and benefit from:}

- Convenient online submission

- Rigorous peer review

- Open access: articles freely available online

- High visibility within the field

- Retaining the copyright to your article

Submit your next manuscript at $\boldsymbol{\nabla}$ springeropen.com 